\title{
BIOLOGY OF FLOWERING AND NECTAR PRODUCTION IN THE FLOWERS OF THE BEAUTY BUSH (Kolkwitzia amabilis Graebn.)
}

\author{
Marta Dmitruk \\ Department of Botany, University of Life Sciences in Lublin, Akademicka 15, 20-950 Lublin, Poland \\ e-mail: marta.dmitruk@up.lublin.pl
}

Received: 12.08 .2012

\begin{abstract}
Nectar production and the morphology of the nectary and pollen grains of Kolwitzia amabilis Graebn. were studied during the period 2008-2009 and in 2011. The blooming of beauty bush flowers started in the third decade of May and ended in the middle of June; flowering lasted 22-23 days. The flower life span was 4-5 days. Nectar production began at the bud break stage. The tube of the corolla in beauty bush flowers forms a spur inside which the nectary is located. The secretory surface of the nectary consists of two layers of glandular epidermal outgrowths: unicellular trichomes, with their length ranging 54.6 $\mu \mathrm{m}-70.2 \mu \mathrm{m}$, and papillae with a length of $13.0 \mu \mathrm{m}-20.6 \mu \mathrm{m}$. The mean weight of nectar per 10 flowers, determined for the three years of the study, was $8.6 \mathrm{mg}$, with a sugar concentration of $50.8 \%$. The weight of nectar sugar was on average $4.4 \mathrm{mg}$. In terms of the size, beauty bush pollen grains are classified as medium-sized. These are tricolporate grains.
\end{abstract}

Key words: nectar, morphology, nectar production, pollen morphology, Kolkwitzia amabilis Graebn.

\section{INTRODUCTION}

The beauty bush (Kolkwitzia amabilis Graebn.) is the only representative of the genus Kolkwitzia which is little known in Poland; this genus belongs to the family Caprifoliaceae which is represented in great numbers in moderate climate zone. The mountains of central China are the natural habitat for this plant. In Poland this species is planted mainly in botanical gardens. The beauty bush is an ornamental shrub that grows to a height of $2.5 \mathrm{~m}$. Entire or slightly toothed leaves, reaching a length of up to $7 \mathrm{~cm}$ and hairy on both sides, grow on arching branches. This plant blooms very abundantly at the end of May or at the beginning of June (S e $n$ e $t$ a, 1983). The flowers, giving off a delicate scent, are five-sepalled and are borne in clusters of several or dozen or so. They produce inflorescences $5-7 \mathrm{~cm}$ long. The calyx is fused into a long narrow tube with 5 sepals at the tip. The pink-coloured campanulate corolla has a yellow to orange spot in the throat. There are four stamens, didynamous, and one pistil.

Taking into account the structure of the ovary and the nature of the pericarp, M a c i e jew ska (1999) says that the nut is the biological type of the beauty bush fruit. Beauty bush flowers are readily visited by Apidae (K o ł t o w s k i , 2006). G ó r s k a - Z a j ą c zk ow ska (1983) claims that this a species with seasonal growth well synchronised with the phenological seasons in Poland. She recommends the beauty bush for gardens and parks, both in the form of larger groups and solitary individuals.

The aim of the present study was to investigate nectar production as well as the morphology of the nectary and pollen grains of the beauty bush. Its decorative and functional values as well as low cultivation requirements might encourage widespread planting of the beauty bush in municipal parks and gardens, green spaces in housing estates, and home gardens.

\section{MATERIALS AND METHODS}

The study was carried out during the period 2008-2009 and in 2011. The beauty bush (Kolkwitzia amabilis Graebn.) shrubs grew in the Botanical Garden of the Maria Curie-Skłodowska University in Lublin, in a sunny location on loess-derived loamy soil.

Time and duration of flowering as well as the life span of a single flower were determined.

The nectar production rate was measured using the pipette method (Jabłoński and Szklanow$\mathrm{s} \mathrm{k} \mathrm{a}, 1979)$. In each year of the study, nectar was collected 4 times on different dates. A single sample consisted of 10 to 60 flowers. Nectar was collected during 
the entire flower lifetime. The percentage nectar sugar content was determined using a refractometer. The average weight of nectar sugar produced by 10 flowers was calculated.

In order to determine the location and type of the floral nectaries, the collected flowers were fixed in $70 \%$ ethanol and subsequently semi-permanent slides were made.

Glycerol-gelatin-coated microscope slides were prepared for pollen measurements. The length of the equatorial (E) and polar (P) axis as well as exine thickness were measured under a light microscope. The P/E ratio was calculated. Using the semi-permanent slides, images of the nectaries and pollen grains of beauty bush were taken under a light microscope.
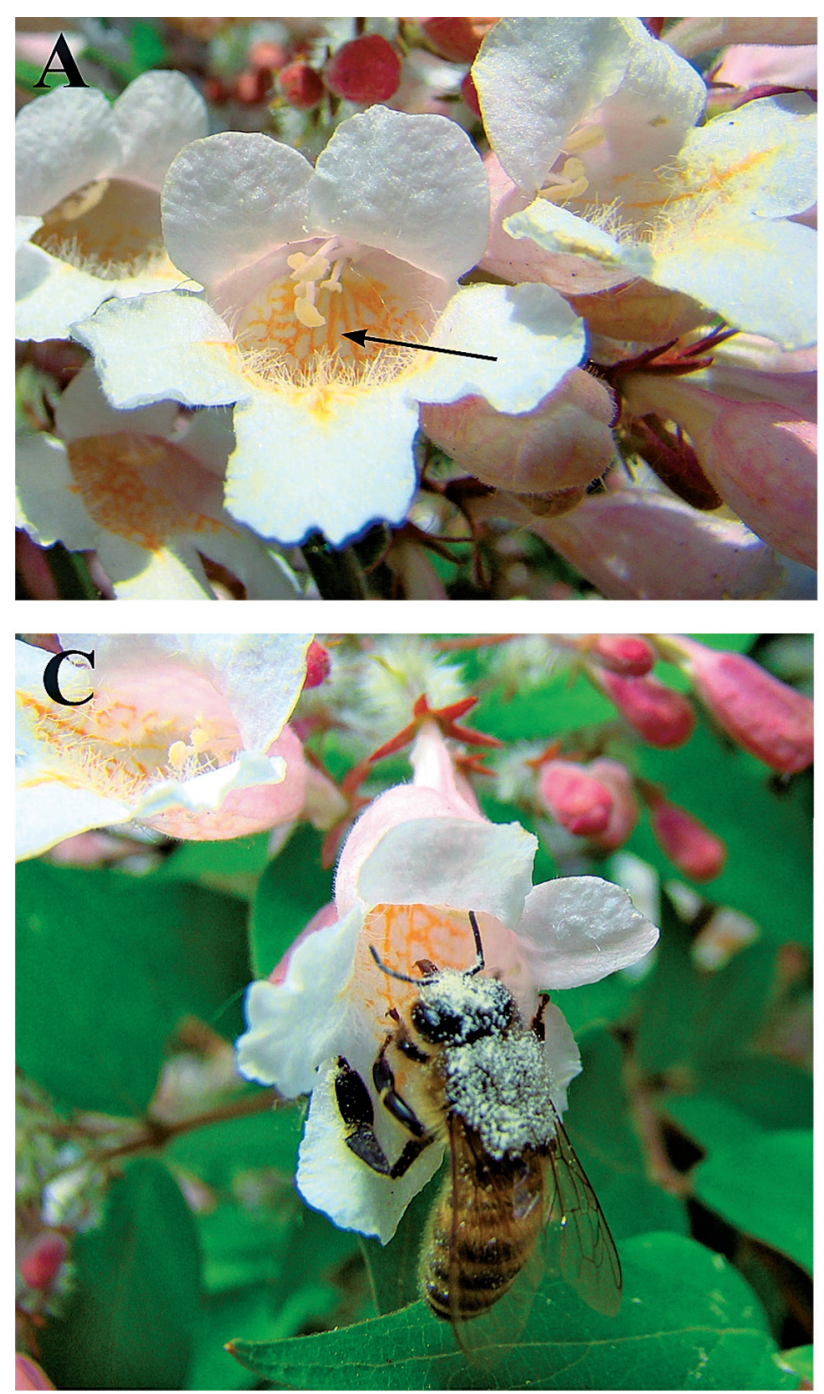

Fig. 1. A-D. Flowers of Kolkwitzia amabilis. A. Orange striae (arrow) are visible by the inlet to the corolla throat. B,C. Insects visiting the beauty bush flowers. D. The location of the nectary is marked with an arrow in the figure.

Nectar was observed in the corolla tube of the flowers already at bud break. At the base of the corolla tube, there is a one-sided projection in the shape of

\section{RESULTS}

Irrespective of the year, flowering of Kolkwitzia amabilis flowers started in the third decade of May and ended after about 3 weeks (2008: 29 May - 19 June; 2009: 25 May - 16 June). In both years, the duration of flowering was very similar (22, 23 days).

The flower life span was 4-5 days. A network of orange striae was noticeable in the throat of the corolla; it formed a spot which was visible from a distance (Fig. 1A) and which became pale in an aging flower. The corollas frequently fell off before the desiccation of petals. The beauty bush flowers were visited in large numbers by honey bees and bumblebees (Fig. 1B-D).
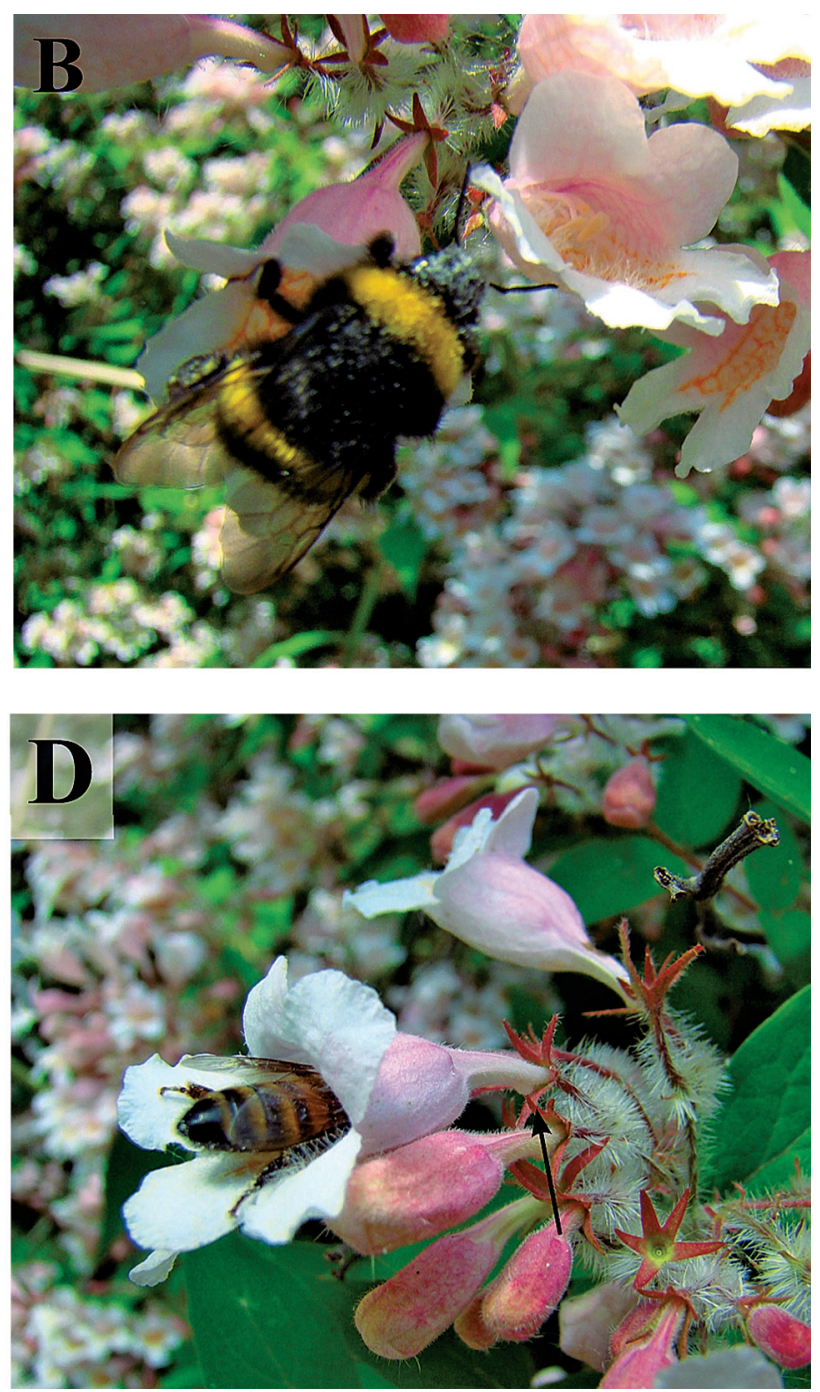

a rounded spur (Fig. 1D). The nectary occupies the inside part of this spur (Fig. 2A). The secretory surface of the nectary consists of two layers of glandular 
epidermal outgrowths of varying height. The upper layer is composed of unicellular trichomes, while the lower layer is made up of papillae that are smaller than the trichomes. The glandular trichomes are oval- or clubshaped, and they are often arched. Their length ranges 54.6-70.2 $\mu \mathrm{m}$. The length of the epidermal outgrowths in the form of papillae is 13.0-20.6 $\mu \mathrm{m}$ (Fig. 2B-F).

The mean weight of nectar per 10 flowers, determined for the three years of the study, was $8.6 \mathrm{mg}$, with a sugar concentration of $50.8 \%$. The highest amount of nectar was recorded in the first year of the study - $2008(9.5 \mathrm{mg})$, while the lowest one in 2011 (7.4 mg). The nectar sugar concentration in 2009 was lower than in the years 2008 and 2011 by $26 \%$ and $39 \%$, respectively. The lower percentage sugar content recorded in 2009 could have resulted from higher rainfall in June of that year. The mean weight of nectar sugar during the study years was $4.4 \mathrm{mg}$ (Table 1).
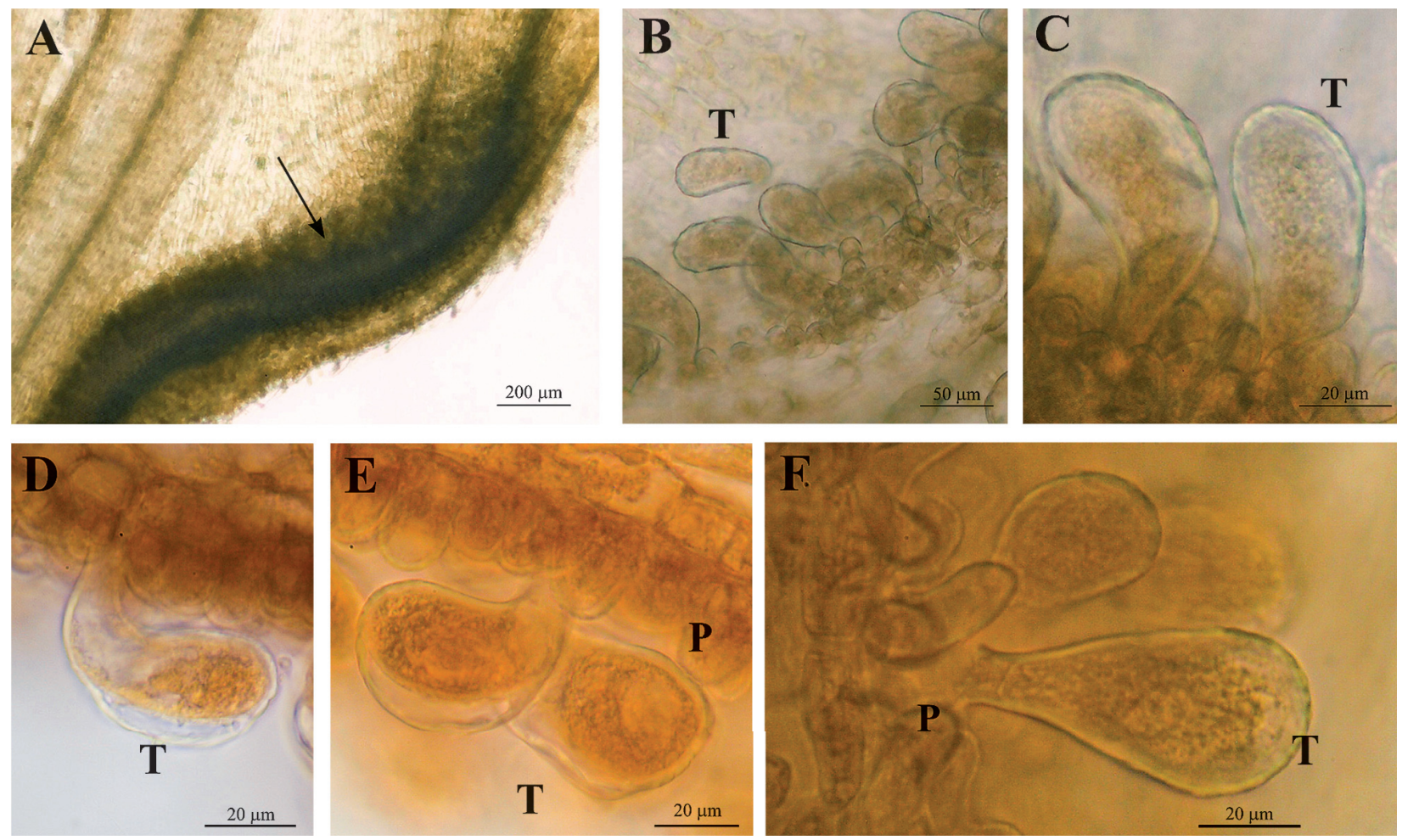

Fig 2. A-F. Portions of the nectary of beauty bush. A. Location of the nectary in the spur of the flower (arrow). B-F. Secretory trichomes $(\mathrm{T})$ and papillae $(\mathrm{P})$ of the nectary.

Table 1

Nectar production per 10 flowers of Kolkwitzia ambilis Graebn.

\begin{tabular}{|c|c|c|c|c|c|c|c|}
\hline \multirow{2}{*}{ Year } & \multirow{2}{*}{$\begin{array}{l}\text { Day and } \\
\text { month }\end{array}$} & \multicolumn{2}{|c|}{ Nectar amount [mg] } & \multicolumn{2}{|c|}{ Sugars content in nectar [\%] } & \multicolumn{2}{|c|}{ Weight of sugars in nectar [mg] } \\
\hline & & $\begin{array}{c}\text { Range } \\
\text { min.-max. }\end{array}$ & Mean SD & $\begin{array}{c}\text { Range } \\
\text { min.-max. }\end{array}$ & Mean SD & $\begin{array}{c}\text { Range } \\
\text { min.-max. }\end{array}$ & Mean SD \\
\hline \multirow{3}{*}{2008} & 16.06 & $6.0-10.0$ & $8.4 \pm 1.93$ & $51.0-51.0$ & $51.0 \pm 0.04$ & $3.06-5.1$ & $4.3 \pm 0.83$ \\
\hline & 23.06 & $10.0-11.0$ & $10.5 \pm 0.41$ & $40.0-63.0$ & $51.0 \pm 8.21$ & $4.0-6.93$ & $5.4 \pm 0.78$ \\
\hline & Mean & & $9.5 \pm 1.7$ & & $51.2 \pm 5.38$ & & $4.8 \pm 1.0$ \\
\hline \multirow{3}{*}{2009} & 9.06 & $5.7-17.3$ & $10.3 \pm 4.97$ & $42.5-50.0$ & $46.7 \pm 3.84$ & $2.41-8.63$ & $4.8 \pm 2.67$ \\
\hline & 14.06 & $6.3-8.7$ & $7.7 \pm 0.27$ & $29.5-30.5$ & $30.0 \pm 0.4$ & $1.87-2.64$ & $2.5 \pm 0.11$ \\
\hline & Mean & & $9.0 \pm 3.42$ & & $38.3 \pm 9.3$ & & $3.6 \pm 2.16$ \\
\hline \multirow{3}{*}{2011} & 3.06 & $5.2-8.3$ & $6.9 \pm 1,33$ & $56.5-60.0$ & $58.2 \pm 1.43$ & $2.95-5.0$ & $4.0 \pm 0.75$ \\
\hline & 14.06 & $8.0-8.1$ & $8.0 \pm 0.04$ & $65.0-70.0$ & $67.5 \pm 2.04$ & $5.2-5.67$ & $5.4 \pm 0.19$ \\
\hline & Mean & & $7.4 \pm 1.1$ & & $62.8 \pm 5.21$ & & $4.7 \pm 0.91$ \\
\hline \multicolumn{2}{|c|}{ Mean } & & $8.6 \pm 2.37$ & & $50.8 \pm 12.16$ & & $4.4 \pm 1.49$ \\
\hline
\end{tabular}


There are four didynamous stamens in the beauty bush flower. Pollen shed begins after the corolla lobes become fully open. Bees sprinkled with pollen form light-coloured pollen loads. In beauty bush pollen grains, the average length of the equatorial axis is $49.7 \mu \mathrm{m}$, while that of the polar axis is $39.5 \mu \mathrm{m}$. In terms of their dimension, they are classified as medium-size. Due to the equatorial to polar axis ratio ( $\mathrm{P} / \mathrm{E}$ ratio), which is 0.8 , these pollen grains are considered to be suboblate. These are tricolporate grains and the average length of the colpi is $21.7 \mu \mathrm{m}$, while their average width is $10.5 \mu \mathrm{m}$. The exine thickness is $1.9 \mu \mathrm{m}$ (Fig. 3A-C, Table 2).
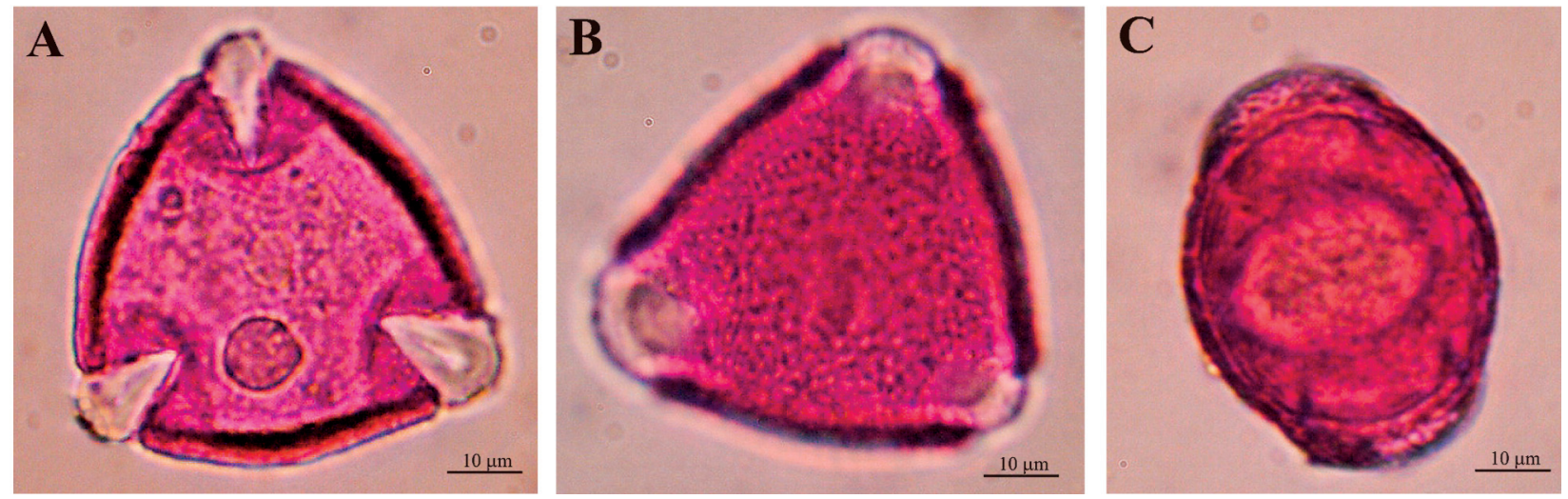

Fig. 3. A-C. Pollen grains of Kolkwitzia amabilis. A. In polar view. B. A view that shows the exine surface. C. In equatorial view.

Table 2

Characteristics of pollen grains of Kolkwitzia amabilis Graebn.

\begin{tabular}{cccc}
\hline \multicolumn{4}{c}{ Feature of pollen grains } \\
\hline \multirow{2}{*}{ Length of axis $[\mu \mathrm{m}]$} & equatorial $[\mathrm{E}]$ & $\begin{array}{c}\text { min.-max. } \\
\text { mean }\end{array}$ & $\begin{array}{c}46.80-54.60 \\
49.68\end{array}$ \\
\cline { 2 - 4 } & polar $[\mathrm{P}]$ & $\begin{array}{c}\text { min.-max. } \\
\text { mean }\end{array}$ & $\begin{array}{c}36.20-44.20 \\
39.55\end{array}$ \\
\hline & $\mathrm{P} / \mathrm{E}$ & & 0.80 \\
\hline
\end{tabular}

\section{DISCUSSION}

In the literature, I did not find any data on the apicultural value of the beauty bush. Kołtow ski (2006) mentions that the species in question is a nectariferous plant that is readily visited by Apidae, but its sugar and pollen yield have not been investigated. Many studies on nectar production, total pollen production, and the morphology of nectaries and pollen grains of other representatives of the family Caprifoliaceae have been conducted. Serological analysis of proteins in seeds of individual species within the family Capripfoliaceae has shown that Kolkwitzia is most closely related to the genera Lonicera and Diervilla (Hillebrand and Fairbrothers, 1970).

Maciejewska (1997) examined the morphology of pollen grains of several species of the family Caprifoliaceae. She determined the size of pollen grains of the following species: Lonicera nigra (E40.8; P-50.7 $\mu \mathrm{m})$, L. tataria (E-47.5; P-52 $\mu \mathrm{m})$, and $L$. xylosteum (E-45.1; P-50.6 $\mu \mathrm{m})$. In terms of their morphology and the length of the polar $(\mathrm{E}-39.5 \mu \mathrm{m})$ and equatorial axis $(\mathrm{P}-49.7 \mu \mathrm{m})$, pollen grains of Kolkwitzia are similar to those of the above-mentioned species of the genus Lonicera.

The beauty bush flowers secret nectar in the tubular corolla and accumulate it in the place of its production. P acini and Nepi (2007) termed this method of offering nectar in Lonicera japonica as primary presentation. S m et s (1986) mentions nectaria trichomalia as one of the nectary types occurring in Lonicera. Wery s zko-Ch mi e lew ska and B ożek (2008) found a trichomatous nectary to occur in the spur of the corolla tube in Lonicera kamtschatica. This nectary consists of unicellular trichomes and smaller papillae. The above-mentioned authors presented the structure of such a nectary also at the ultrastructural level. The secretory surface of the nectary of beauty bush is composed of two layers of glandular epidermal outgrowths: trichomes and papillae.

The beauty bush flowers produced $8.74 \mathrm{mg}$ of nectar per 10 flowers and the weight of nectar sugar ranged from 1.87 to $8.63 \mathrm{mg}$. In the case of European 
fly honeysuckle, Jabłoński and Kołtowski (1993) give higher values of sugar weight which averaged $22.2 \mathrm{mg} / 10$ flowers, similarly as B o ż e k and Wi e niarska (2006) reported the values of 17.77$28.32 \mathrm{mg}$ for different varieties of blue honeysuckle. Szklanowska (1978) showed that the weight of nectar sugar in the flowers of Lonicera xylosteum was $8.74 \mathrm{mg}$, while for L. tatarica it was $1.95 \mathrm{mg}$. The sugar concentration for the studied varieties of Lonicera kamtschatica was 33-36\% (B o ż e k and W i e n i a r$\mathrm{s} \mathrm{k} \mathrm{a,} \mathrm{2006).} \mathrm{In} \mathrm{the} \mathrm{present} \mathrm{study,} \mathrm{a} \mathrm{higher} \mathrm{sugar} \mathrm{con-}$ centration was found in the nectar of beauty bush than in the nectar of other representatives of Caprifoliaceae $(30.0 \%-62.85 \%)$.

\section{CONCLUSIONS}

1. The nectary is located in the inner part of the spur formed by the corolla tube of the beauty bush flowers. The secretory surface consists of unicellular trichomes with a length of $54.6 \mu \mathrm{m}-70.2 \mu \mathrm{m}$ and smaller papillae reaching $13.0 \mu \mathrm{m}-20.6 \mu \mathrm{m}$ in length.

2. The beauty bush flowers produced on average 8.7 $\mathrm{mg}$ of nectar with a sugar concentration of $50.8 \%$. The weight of nectar sugar was on average $4.4 \mathrm{mg}$.

3. Pollen grains of Kolkwitzia amabilis are classified as medium-sized and suboblate.

\section{Acknowledgements}

This research was supported by the Ministry of Science and Higher Education of Poland as part of the statutory activities of the Department of Botany, University of Life Sciences in Lublin.

\section{REFERENCES}

B ożek M., Wieniarska J. 2006. Biologia kwitnienia i wydajność cukrowa kwiatów dwóch odmian Lonicera kamtschatica (Sevast.) Pojark./ Biology of flowering and sugar yield of flowers of two varieties of Lonicera kamtschatica (Sevast.) Pojark. Acta Agrobot. 59 (1): 177-182. (in Polish)

Hillebrand G.R., Fairbrothers D.E. 1970. Phytoserological systematic survey of the Caprifoliaceae. Brittonia 22: 125-133. http://dx.doi.org/10.2307/2805806

Górska-Zajączkowska M. 1983. Rytmika rozwojowa Kolkwitzia amabilis Graebn. w Ogrodzie Botanicznym UAM w Poznaniu./ The growth cycle of Kolkwitzia amabilis Graebn. in the Botanical Garden of the Adam Mickiewicz University in Poznań. Wiad. Bot. 27(2): 131-156. (in Polish)

Kołtowski Z. 2006. Wielki atlas roślin miododajnych. PWRZ SA, Warszawa. (in Polish)

Jabłoński B., Szklanowska K. 1979. Propozycje zmiany metody badań nektarowania roślin./ Proposals for changes in methods of research on nectar production in plants. Pszczeln. Zesz. Nauk. 23: 105-113. (in Polish)

Jabłoński B., Kołtowski Z. 1993. Nektarowanie i wydajność miodowa roślin miododajnych w warunkach Polski. Część VIII./ Nectar production and honey yield of melliferous plants under Polish conditions. Part VIII. Pszczeln. Zesz.Nauk. 37: 81-87. (in Polish)

Maciejewska I. 1997. Pollen morphology of the polish species of the family Caprifoliaceae. Part 2. Acta Soc. Bot. Pol. 66 (2): 143-144.

Macie jewska I. 1999. Notes on fruit development and fruit type of Kolkwitzia amabilis Graebn. Rocz. Dendrol. 47: 77-83.

Pacini E., Nepi M. 2007. Nectar production and presentation. [In:] Nectaries and nectar. S.W. Nicolson, M. Nepi., E. Pacini (eds), Springer, Dordrecht.

S e net a W. 1983. Dendrologia. PWN, Warszawa. (in Polish)

S mets E. 1986. Localization and systematic importance of the floral nectaries in the Magnoliatae (Dicotyledonos). Bull. Jard. Bot. Nat. Belg. 56: 51-76. http://dx.doi. org/10.2307/3667757

Szk la nowska K. 1978. Nektarowanie i wydajność miodowa niektórych drzew i krzewów w warunkach Polski./ Nectar production and honey yield of some trees and shrubs under Polish conditions. Pszczeln. Zesz. Nauk. 22: 117-127. (in Polish)

Weryszko-Chmielewska E., Bożek M. 2008. Structure of trichomatous nectries in flowers of Lonicera kamtschatica (Sevat.) Pojark. Acta Agrobot. 61 (1): 13-26.

\section{Biologia kwitnienia i nektarowanie kwiatów kolkwicji chińskiej (Kolkwitzia amabilis Graebn.)}

\section{Streszczenie}

W latach 2008-2009 i 2011 badano nektarowanie, morfologię nektarnika i ziaren pyłku Kolkwitzia amabilis Graebn. Kwitnienie kwiatów kolkwicji rozpoczynało się $\mathrm{w}$ trzeciej dekadzie maja a kończyło w połowie czerwca i trwało 22-23 dni. Długość życia kwiatu wynosiła 4-5 dni. Nektarowanie rozpoczynało się w stadium luźnego pąka. Rurka korony kwiatów kolkwicji tworzy ostrogę, wewnątrz której znajduje się nektarnik. Powierzchnię sekrecyjną nektarnika stanowią dwie warstwy wydzielniczych wytworów epidermy: jednokomórkowe trichomy, o długości zawartej w przedziale $54,6 \mu \mathrm{m}-70,2 \mu \mathrm{m}$, oraz papille o długośći 13,0 $\mu \mathrm{m}-20,6 \mu \mathrm{m}$. Średnia masa nektaru z 10 kwiatów określona w ciągu trzech lat wynosiła 8,6 mg, przy koncentracji cukrów 50,8\%. Masa cukrów wynosiła średnio 4,4 mg. Ze względu na wielkość ziarna pyłku kolkwicji zaliczane są do średnich. Są to ziarna trójbruzdowoporowe (tricolporate). 
